\title{
Lipid profile and cholesterol of pork with the use of glycerin in feeding
}

\author{
[Perfil lipídico e colesterol da carne de suínos com uso de glicerina na alimentação] \\ P.B. Faria ${ }^{1}$, V.S. Cantarelli ${ }^{1}$, E.T. Fialho ${ }^{1}$, A.M.B.G. Pinto ${ }^{1}$, J.H. Faria ${ }^{1}$, \\ M.F.M. Rocha', M.C. Guerreiro ${ }^{1}$, M.C. Bressan ${ }^{2}$ \\ ${ }^{1}$ Universidade Federal de Lavras - UFLA- Lavras, MG \\ ${ }^{2}$ Instituto Nacional de Recursos Biológicos - INRB - Santarém, Portugal
}

\begin{abstract}
The aim of this work was to evaluate the effects of adding different levels of glycerin in the feeding on the lipid profile and cholesterol of the meat of finishing pigs. The experiment was arranged in a completely randomized design (CRD) with factorial $5 \times 2$, being five levels of glycerin in the diet and two genders. Sixty (60) swine of the Topigs genetics (30 barrows and 30 gilts) were used; they presented initial average weight of $79.3 \pm 4.0 \mathrm{~kg}$ and were finished with the weight of $106.2 \pm 4.5 \mathrm{~kg}$. The levels of glycerin utilized were $0,50,100,150$ and $200 \mathrm{~g} / \mathrm{kg}$ in the natural matter. The analyses of lipid and cholesterol profile were conducted in the muscles longissimus dorsi (loin) and semimembranosus (ham) on the left side of the carcasses. Interaction occurred between the levels of crude glycerin in the diet and the sexual category for the profile of fatty acids and cholesterol. On the loin the meat of the barrows presented higher means of C16:0, C16:1, C20:3 $13, \mathrm{C} 18: 1 \omega 9 \mathrm{c}$, Total of saturated (SFA) and monounsaturated (MUFA) fatty acids. On the ham, increased means were found

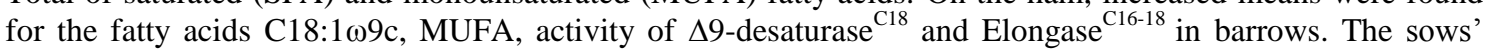
meat presented higher proportions of polyunsaturated fatty acids and of the series $\omega 6$ for both the cuts. The amount of cholesterol in the sows' meat presented increase according to the level of glycerin in the meat. The barrows' meat presented indices of atherogenicity greater than the gilts. The levels of glycerin altered the lipid profile and cholesterol content according to the sexual category, promoting a distinct effect on the loin and ham.
\end{abstract}

Keywords: biofuel, fatty acids, nutritional composition

\section{RESUMO}

O objetivo deste trabalho foi avaliar os efeitos do fornecimento de diferentes níveis de glicerina na alimentação sobre o perfil lipídico e colesterol da carne de suínos em terminação. $O$ delineamento experimental foi organizado inteiramente ao acaso (DIC), com fatorial 5x2, sendo: cinco níveis de glicerina na dieta e dois sexos. Foram utilizados 60 suínos da genética Topigs (30 machos castrados e 30 fêmeas),

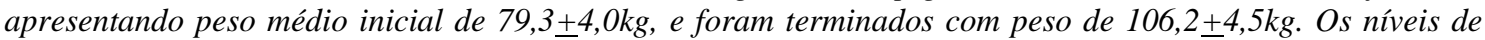
glicerina utilizados foram de 0,50, 100, 150 e $200 \mathrm{~g} / \mathrm{kg}$ na matéria natural. As análises de perfil lipídico e de colesterol foram realizadas nos músculos longissimus dorsi (lombo) e semimembranosus (pernil) do lado esquerdo das carcaças. Ocorreu interação entre os níveis de glicerina bruta na dieta e a categoria sexual para o perfil de ácidos graxos e colesterol. A carne dos machos castrados apresentou no lombo maiores médias de

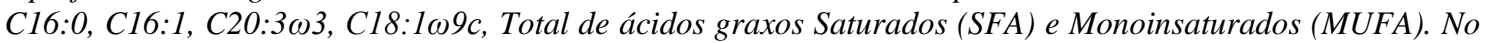

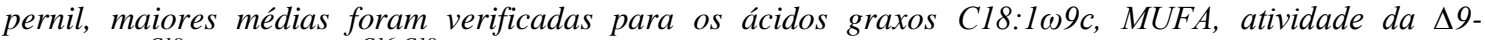
desaturase $^{C 18}$ e Elongase ${ }^{\text {Cl6-C18 }}$ em machos castrados. A carne das fêmeas suínas apresentou maiores proporções de ácidos graxos poli-insaturados e da série $\omega 6$ para ambos os cortes. A quantidade de colesterol na carne das fêmeas suínas apresentou aumento em função do nível de glicerina na dieta. A carne dos machos castrados apresentou maiores índices de aterogenicidade que das fêmeas. Os níveis de glicerina alteraram o perfil lipídico e teor de colesterol em função da categoria sexual, promovendo efeito diferenciado no lombo e pernil.

Palavras-chave: biocombustível, ácidos graxos, composição nutricional

Recebido em 6 de agosto de 2013

Aceito em 7 de agosto de 2014

E-mail: peterbfvet@yahoo.com.br

Apoio financeiro: FAPEMIG - Fundação de Amparo a Pesquisa do Estado de Minas Gerais 


\section{INTRODUCTION}

Crude glycerin is one of the by-products of biodiesel production, its use has been growing in animal feeding as a way of reducing the costs of the diets of the several meat-producing species. Crude glycerin contains glycerol contents ranging from 80 to $95 \%$, this being a precursor for triacylglycerol and phospholipids synthesis in the liver and adipose tissue (Boyle, 2005; Cerrate et al., 2006).

In general pork presents a predominance of the

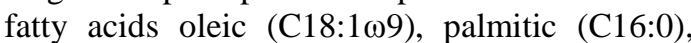

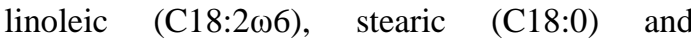

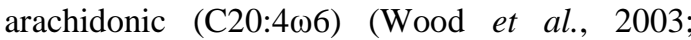
Nuernberg et al., 2005; Teye et al., 2006). Nevertheless, one of the main factors which lead to the deposition of fatty acids as well as their profiles, is the feeding that the animals receive (Mitchaothai et al., 2007).

However, the increase in the level of information of the world population as to the importance of a diet with lower levels of saturated fat has led to increased search for meats which present, in their characteristics, better balance between saturated, monounsaturated and polyunsaturated fatty acids and low ratio $\omega 6 / \omega 3$. The content in essential fatty acids plays an outstanding role in human nutrition, since they are integrant of cell structures and precursors of the synthesis of several substances essential to the maintenance of the physiological processes (Perini et al., 2010).

In this way, studies should be conducted on crude glycerin, since glycerol is utilized in lipogenesis and even in gluconeogenesis, which could contribute towards the increase in the lipid contents and modification of the lipid profile in pork.

\section{MATERIAL AND METHODS}

The animals were reared in the Finishing House of the Swine Culture Sector of the Animal Science Department of the Federal University of Lavras (UFLA) in the municipality of Lavras MG. Thirty barrows and 30 gilts of the genetics Topigs, with initial average weight of $79.3 \pm 4.00 \mathrm{~kg}$ and finished with weight of
$106.2 \pm 4.5 \mathrm{~kg}$ were utilized. This study was approved by the Ethics Committee on Animal Use UFLA with protocol number 011/2010. The experiment was arranged in a completely randomized design (CRD) with factorial $5 \times 2$, being five levels of glycerin in the diet $(0,50$, 100,150 and $200 \mathrm{~g} / \mathrm{kg}$ ) and two genders (male (barrow) and female (gilt)), with 6 replicates per treatment and each experimental unit consisted of one animal, totaling 60 pigs. The experimental diets were formulated on the basis of corn and soybean meal, supplemented with vitamins, minerals and aminoacids to meet the minimum requirements for barrows of high genetic potential from 70 to $100 \mathrm{~kg}$ (Table 1) with the utilization of different levels of crude glycerin.

The treatments were carried out in the following way: Treatment 1 - basal diet without the addition of glycerin; Treatment $2-50 \mathrm{~g} / \mathrm{kg}$ of glycerin instead of corn in the basal diet in the natural matter; Treatment $3-100 \mathrm{~g} / \mathrm{kg}$ of glycerin instead of corn in the basal diet in the natural matter; Treatment $4-150 \mathrm{~g} / \mathrm{kg}$ of glycerin instead of corn in the basal diet in the natural matter and, Treatment $5-200 \mathrm{~g} / \mathrm{kg}$ of glycerin instead of corn in the basal diet in the natural matter. The animals were given water and feed ad libitum during the experimental period of 30 days.

At the end of the experiment, after fasting and water diets for 12 hours' time, the animals were slaughtered under humanitarian conditions through electric insensibilization (electronarcosis) with later bleeding and evisceration.

After 24 hours' cooling of the carcasses in cold room $\left( \pm 5^{\circ} \mathrm{C}\right)$, the collection of the samples of the muscles Longissimus dorsi (loin) and Semimembranosus (ham) on the left side of the carcasses was done. The samples were carried refrigerated into the Laboratory and then they were frozen for later determination of the lipid profile in the Meat and Fish Technology and Chromatography Laboratory in the Chemistry Department. For determination of the fatty acid profile, samples of the muscle Longissimus dorsi (loin) and Semimembranosus (ham) after thawing at $5^{\circ} \mathrm{C}$ for 24 hours in a refrigerator were utilized. 
Lipid profile and cholesterol...

Table 1. Centesimal composition and values calculated in the experimental diets

\begin{tabular}{|c|c|c|c|c|c|}
\hline \multirow{2}{*}{ Ingredients } & \multicolumn{5}{|c|}{ Levels of glycerin ${ }^{1}(\mathrm{~g} / \mathrm{kg}$ of natural matter) } \\
\hline & 0 & 50 & 100 & 150 & 200 \\
\hline Ground corn & 707 & 654.5 & 603.0 & 551.0 & 499.0 \\
\hline Soybean meal & 229 & 238 & 247 & 258 & 266 \\
\hline Crude glycerin & 0 & 50 & 100 & 150 & 200 \\
\hline Soybean oil & 20.0 & 16.8 & 13.3 & 9.0 & 5.9 \\
\hline Bicalcium phosphate & 11.2 & 11.2 & 11.2 & 11.2 & 11.2 \\
\hline Calcitic limestone & 7.7 & 7.7 & 7.7 & 7.7 & 7.7 \\
\hline Salt $(\mathrm{NaCl})$ & 3.6 & 1.35 & 0 & 0 & 0 \\
\hline Mineral Premix ${ }^{2}$ & 1.0 & 1.0 & 1.0 & 1.0 & 1.0 \\
\hline Vitamin Premix ${ }^{3}$ & 1.0 & 1.0 & 1.0 & 1.0 & 1.0 \\
\hline DL-Metionina 99 & 0.09 & 0.1 & 0.1 & 0.1 & 0.15 \\
\hline L-Lysine 99 & 1.5 & 1.35 & 1.2 & 1.0 & 0.9 \\
\hline L-Threonine 98 & 0.07 & 0.07 & 0.07 & 0.07 & 0.07 \\
\hline Tylan $^{4}$ & 0.2 & 0.2 & 0.2 & 0.2 & 0.2 \\
\hline Caulim & 17.64 & 16.73 & 14.23 & 9.73 & 6.88 \\
\hline \multicolumn{6}{|l|}{ Calculated Values } \\
\hline Metabolizabale Energy (KCal/kg) & 3.250 & 3.250 & 3.250 & 3.250 & 3.250 \\
\hline Digestible Lysin (g/kg) & 8.19 & 8.21 & 8.23 & 8.27 & 8.31 \\
\hline Digestible Methionine (g/kg) & 2.50 & 2.50 & 2.50 & 2.50 & 2.50 \\
\hline Crude protein $(\mathrm{g} / \mathrm{kg})$ & 160,2 & 160.2 & 160.2 & 160.2 & 160.2 \\
\hline Digestible threonine $(\mathrm{g} / \mathrm{kg})$ & 5.50 & 5.50 & 5.50 & 5.50 & 5.50 \\
\hline Available phosphosrus $(\mathrm{g} / \mathrm{kg})$ & 3.00 & 3.00 & 3.00 & 3.00 & 3.00 \\
\hline Calcium $(\mathrm{g} / \mathrm{kg})$ & 6.50 & 6.50 & 6.50 & 6.50 & 6.50 \\
\hline
\end{tabular}

For the analysis of cholesterol and fatty acids (FA), lipids were extracted according to the procedures described by Folch et al. (1957) being esterified and separated (Hartman and Lago, 1973). Cholesterol was quantified by colorimetry, with a modification of the method of Bohac et al. (1988), as described by Bragagnolo and Rodriguez-Amaya (2002) and the results were expressed in $\mathrm{mg} / 100 \mathrm{~g}$ of meat.

The analysis of fatty acids was done by gas chromatography in a chromatograph Shimatzu CG 2010 (Agilent Technologies Inc., Palo Alto, CA, USA), equipped with a flame ionization detector, split injector at the rate of $1: 50$ and capillary column of Supelco SP ${ }^{\mathrm{TM}}-2560,100 \mathrm{~m} \mathrm{X}$ $0.25 \mathrm{~mm}$ X $0.20 \mu \mathrm{m}$ (Supelco Inc., Bellefonte, PA, USA). The chromatographic conditions were initial temperature of the column of $140^{\circ} \mathrm{C} / 5$ minutes; increased $4^{\circ} \mathrm{C} /$ minute to $240^{\circ} \mathrm{C}$ and kept for 30 minutes, amounting to 60 minutes. The injector temperature was $260^{\circ} \mathrm{C}$ and that of the detector $260^{\circ} \mathrm{C}$. The carrier gas utilized was helium. The fatty acids were identified by comparison with the retention times presented by the chromatographic standard Supelco $^{\mathrm{TM}_{37}}$ standard FAME Mix (Supelco Inc., Bellefonte, PA, USA) and expressed in percentage (\%) of the total of fatty acids identified and afterwards grouped together into: Total of Saturated Fatty Acids (SFA), Total of Monounsaturated Fatty Acids (MUFA) and Total of Polyunsaturated Fatty Acids (PUFA).

The activity of enzyme $\Delta^{9}$ desaturase and elongase was estimated according to MalauAduli et al. (1998) and Kazala et al. (1999). The indices of atherogenicity and thrombogenicity, considered as a health indicator related to the risk of cardiovascular disease, were computed according to Ulbricht and Southgate (1991).

The data were surveyed by the statistic program SISVAR®. The variables for analysis of variance for the factors levels of glycerin and gender and/or interaction among them were analyzed by the SNK Test $(\alpha=0.05)$. 


\section{RESULTS AND DISCUSSION}

The use of different levels of crude glycerin showed distinct efficiency in the lipid profile of the loin for the sexual categories utilized, an interaction among these factors being found for the following fatty acids: pentadecanoic (C15:0); stearic (C18:0); Oleic

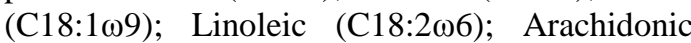

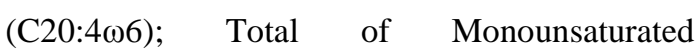
acids (MUFA); Total of Polyunsaturated acids (PUFA); Total of $\omega 6$; Ratio Polyunsaturated/Saturated acids (PUFA/SFA); Activity of $\Delta 9$-desaturase ${ }^{\text {C16 }}$; Activity of $\Delta 9$ desaturase $\mathrm{C}^{\mathrm{C} 18}$; Activity of Elongase C16-C18 (Table 2).

Table 2. Composition of the fatty acids of the loin of pigs depending on the glycerine level of feeding and gender

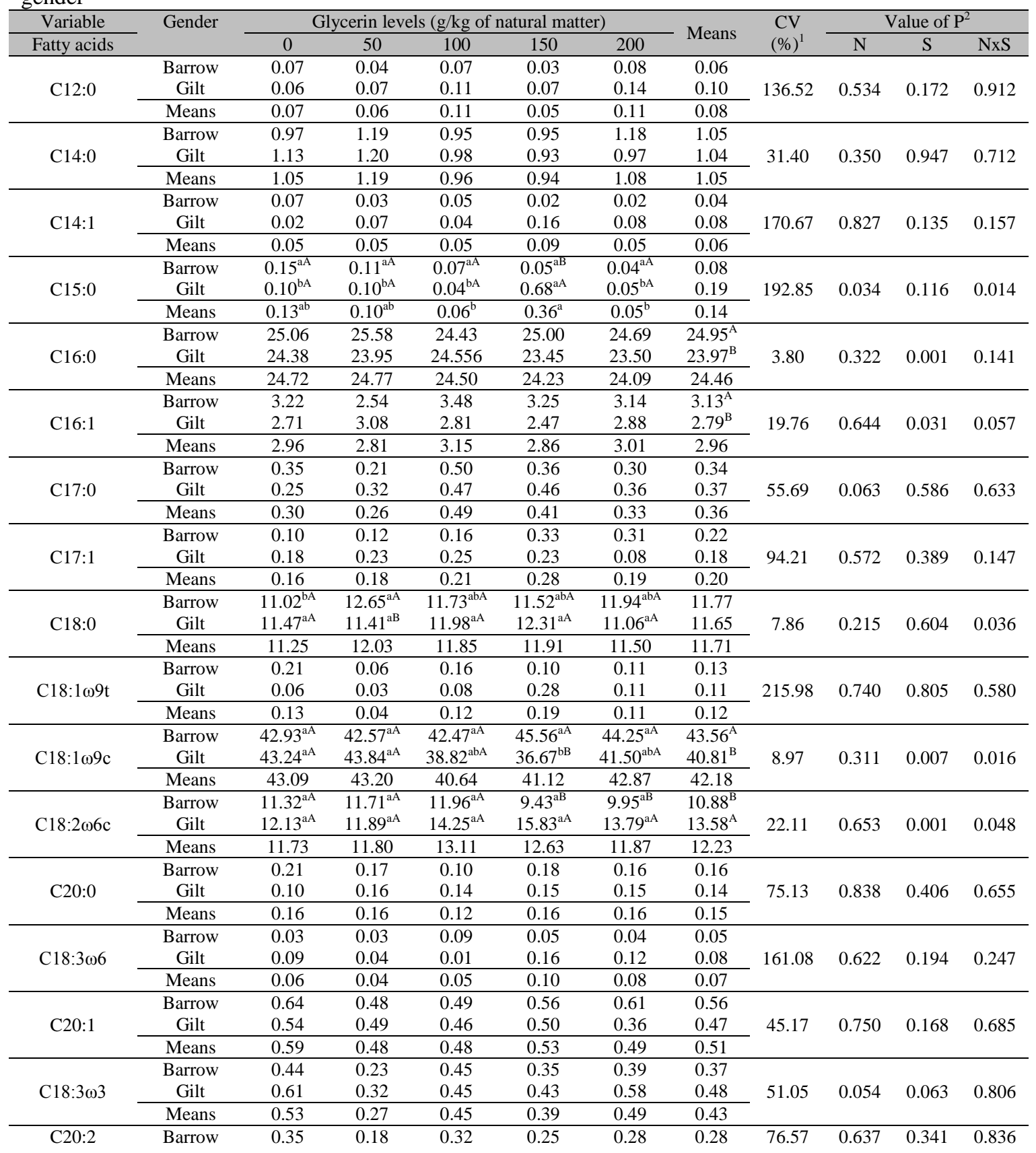


Lipid profile and cholesterol...

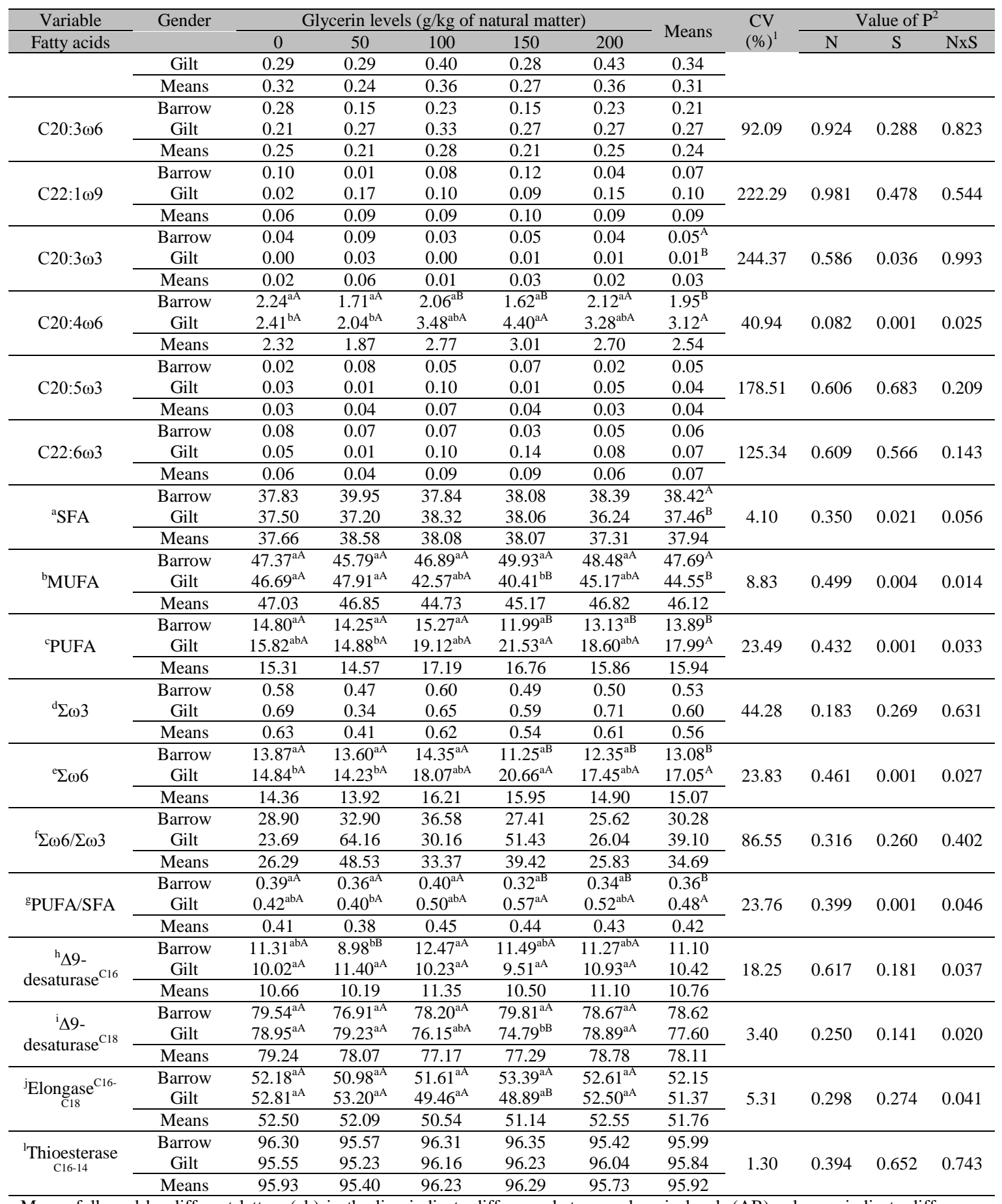

Means followed by different letters (ab) in the line indicate difference between glycerin level; (AB) columna indicate difference between sex by SNK test $(\alpha=0,05)$. ${ }^{1}$ Coefficient of variation; ${ }^{2} \mathrm{~N}, \mathrm{~S}, \mathrm{~N}$ x S: effect of the supplementation with glycerin level, sex

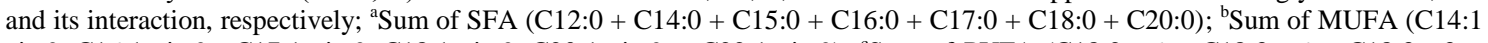
cis-9+C16:1 cis-9+ C17:1 cis-9+C18:1 cis-9+C20:1 cis-9 + C22:1 cis-9); ${ }^{\mathrm{c}}$ Sum of PUFA $(\mathrm{C} 18: 2 \omega-6+\mathrm{C} 18: 3 \omega-6+\mathrm{C} 18: 3 \omega-3+$ $\mathrm{C} 20: 4 \omega-6+\mathrm{C} 20: 3 \omega 6+\mathrm{C} 20: 3 \omega 3+\mathrm{C} 20: 5 \omega 3+\mathrm{C} 22: 6 \omega-3) ;{ }^{\mathrm{d}} \mathrm{Sum}$ of PUFA of the n-6 series $(\mathrm{C} 18: 2 \omega-6+\mathrm{C} 18: 3 \omega-6+\mathrm{C} 20: 4 \omega-6+$ $\mathrm{C} 20: 3 \omega 6)$; ${ }^{\mathrm{e}} \mathrm{Sum}$ of PUFA of the $\mathrm{n}-3$ series $(\mathrm{C} 18: 3 \omega-3+\mathrm{C} 20: 3 \omega 3+\mathrm{C} 20: 5 \omega 3+\mathrm{C} 22: 6 \omega-3)$; ${ }^{\mathrm{f}} \mathrm{Ratio}$ PUFA/SFA $(\mathrm{C} 18: 2 \omega-6+\mathrm{C} 18: 3 \omega-$ $6+\mathrm{C} 18: 3 \omega-3+\mathrm{C} 20: 4 \omega-6+\mathrm{C} 20: 3 \omega 6+\mathrm{C} 20: 3 \omega 3+\mathrm{C} 20: 5 \omega 3+\mathrm{C} 22: 6 \omega-3) /(\mathrm{C} 12: 0+\mathrm{C} 14: 0+\mathrm{C} 15: 0+\mathrm{C} 16: 0+\mathrm{C} 17: 0+\mathrm{C} 18: 0+$ C20:0); ${ }^{\mathrm{g}}$ Ratio $\omega-6 / \omega-3(\Sigma \omega-6 / \Sigma \omega-3) ;{ }^{\mathrm{h}}$ Index of $\mathrm{C} 16$ desaturase activity=100 [(C16:1 cis-9)/(C16:1 cis-9+C16:0)]; ${ }^{\mathrm{i}}$ Index of C18 desaturase activity $=100\left[\left(\mathrm{C} 18: 1\right.\right.$ cis-9)/(C18:1 cis-9+C18:0)]; ${ }^{j}$ Index of $\mathrm{C} 16$ to $\mathrm{C} 18$ elongase activity $=100 \quad[(\mathrm{C} 18: 0+\mathrm{C} 18: 1$ cis9)/(C16:0+C16:1 cis-9+C18:0+C18:1 cis-9)]; Index of C16 to C14 thioesterase activity=100 [(C16:0)/(C16:0+C14:0)]. 
Only the influence of the glycerin levels on the values in the loin of fatty acids C15:0 with highter means for $150 \mathrm{~g} / \mathrm{kg}$ (Table 2) were isolated. The gender influence on the values of fatty acids palmitic (C16:0); palmitoleic (C16:1);

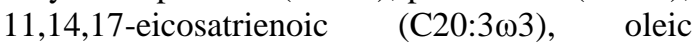
$(\mathrm{C} 18: 1 \omega 9 \mathrm{c})$, Total of saturated fatty (SFA) and monounsaturated (MUFA) acids, with higher means for the barrows, were similar to that reported by Nuernberg et al. (2005), Tikk et al. (2007), Zhang et al. (2007), Alonso et al. (2009) and Mas et al. (2010).

The barrows had higher values of palmitic fatty acids (C16:0), palmitoleic (C16:1), C20:3 03 and Total of Saturated Faty acids (SFA) in the loin, ham here while in the more meas of MUFA, activity of $\Delta 9$-desaturase ${ }^{\mathrm{C} 18}$ and Elongase ${ }^{\text {C16-C18 }}$.

For the loin, there was distinct behavior of the glycerin levels according to the gender, revealing that effect in the barrows for the fatty acid oleic (C18:0) and activity of enzyme $\Delta 9$-desaturase ${ }^{\mathrm{C} 16}$ with $50 \mathrm{~g} / \mathrm{kg}$ and $100 \mathrm{~g} / \mathrm{kg}$ glicerin levels, respectively. In the gilts, poorer amounts of oleic acid (C18:109) were found, which showed a decrease along with the activity of the enzyme $\Delta 9$-desaturase ${ }^{\mathrm{C} 18}$ and Elongase ${ }^{\mathrm{C} 16-\mathrm{C} 18}$ according to the levels of glycerin of $150 \mathrm{~g} / \mathrm{kg}$ in the diet, which brought about similar behavior and the reduction of the total of monounsaturated fatty acids (MUFA) compared to barrows and glicerin levels.

Interaction was verified between the glycerin levels and gender, which revealed the C15:0,

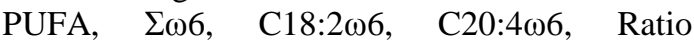
PUFA/SFA for the $150 \mathrm{~g} / \mathrm{kg}$ glicerin level means for gilts (Table 2), which showed that dietary levels of glycerin interfered in the fatty acids composition of the meat of gilts in relation to the series w6 fatty acids to increase the amounts of polyunsaturated fatty acids, while in barrows this effect did not occur. In general barrows present increased lipogenesis activity than the gilts. That effect is due to the absence of anabolic stimuli, since androgens exercise a direct effect upon the musculature and estrogens promote a greater release of growth hormone and insulin-like growth factor (IGF-I), increasing the deposition of aminoacids and glucose into the muscle (Clapper et al., 2000). The results found in this study may be related to the increased rate of intramuscular and subcutaneous deposition of lipids that is supported by emasculation, promoting a greater deposition of saturated fatty acids, whereas in the gilts, higher concentrations of polyunsaturated fatty acids are found in total lipids or triacylglycerols (Alonso et al., 2009; Mas et al., 2010).

There was an influence of the glycerin levels on the values of fatty acids identified in the ham, regardless of gender (Table 3). For the ham, greater means of the fatty acids oleic

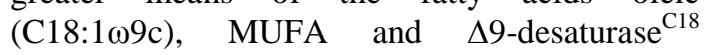
activity were found in barrows. These results may be related to a greater activity of the enzymes Elongase ${ }^{\mathrm{C} 16-\mathrm{C} 18}$ (Table 3) and $\Delta 9$ desaturases in the barrows meat, since this acts in the removal of hydrogen molecules of the carbonated chains of saturated fatty acids, increasing the formation of monounsaturated fatty acids cis-9, such as palmitoleic and oleic (Hayashi et al., 2007; Metz et al., 2009).

In the ham there was interaction between gender and glycerin level with the fatty acid palmitic (C16:0) with higher averages for barrows compared to gilts at the level of 100 and $200 \mathrm{~g} / \mathrm{kg}$; whereas in gilts a change in the Thioesterase activity was observed on the glycerin level, which showed higher means for $150 \mathrm{~g} / \mathrm{kg}$ and they had smaller averages than barrows of $100 \mathrm{~g} / \mathrm{kg}$ glycerin level (Table 3 ). The sexual categories showed influence upon the lipid profile of the loin and ham of pigs and the results found reveal that in general the barrows presented higher values of oleic acid (C18:169c) in both the cuts, while the gilts had greater means for polyunsaturated fatty acids (Linoleic

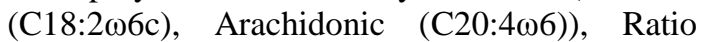
PUFA/SFA and the series $\omega 6$, highlighting PUFA, were observed, which contributed towards the reduction of the indices of atherogenicity and thrombogenicity when as compared with the meat of the barrows (Table 4). 
Lipid profile and cholesterol...

Table 3. Composition of the fatty acids of the swine ham according to the glycerin level of feeding and gender

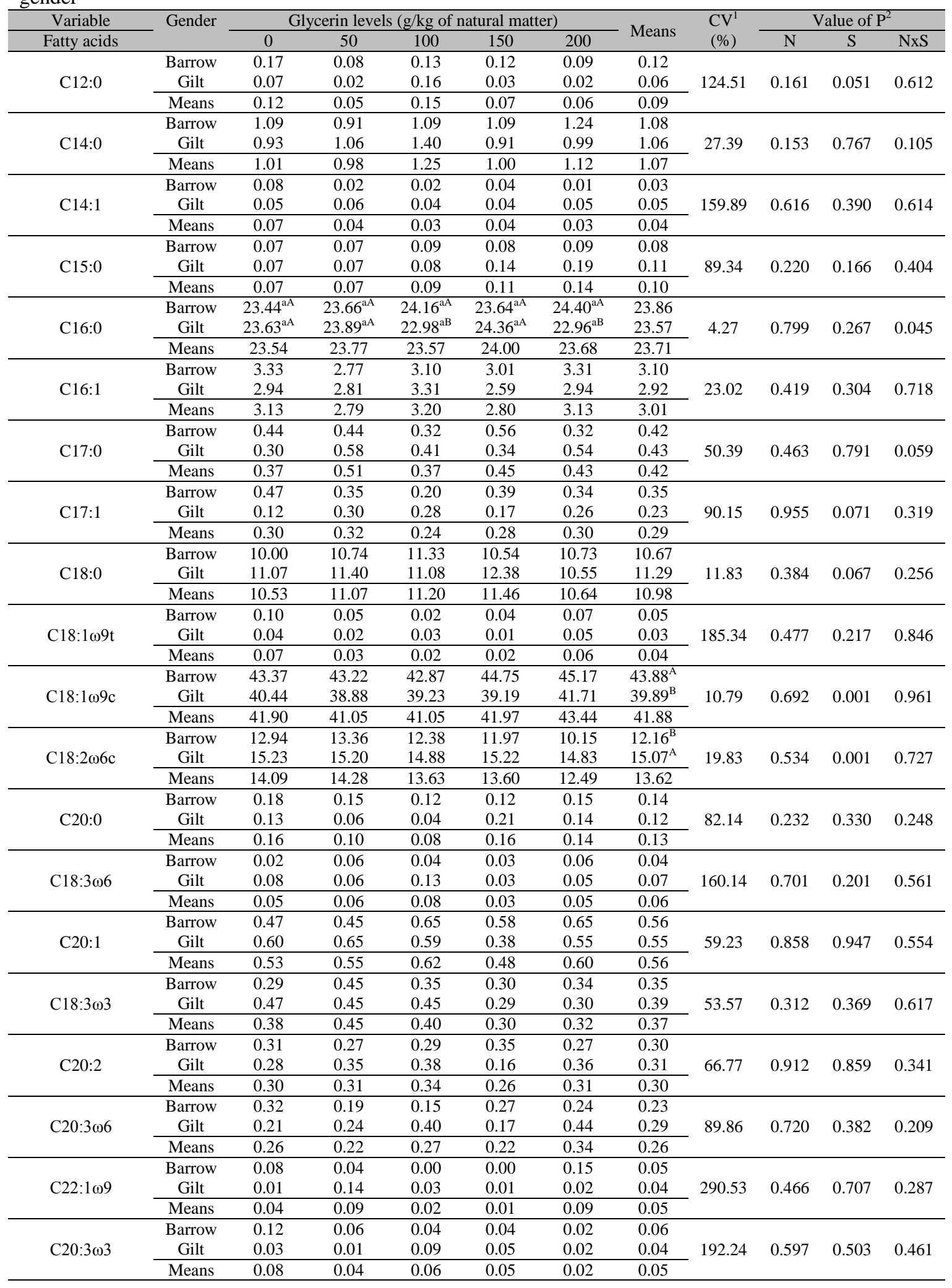


Faria et al.

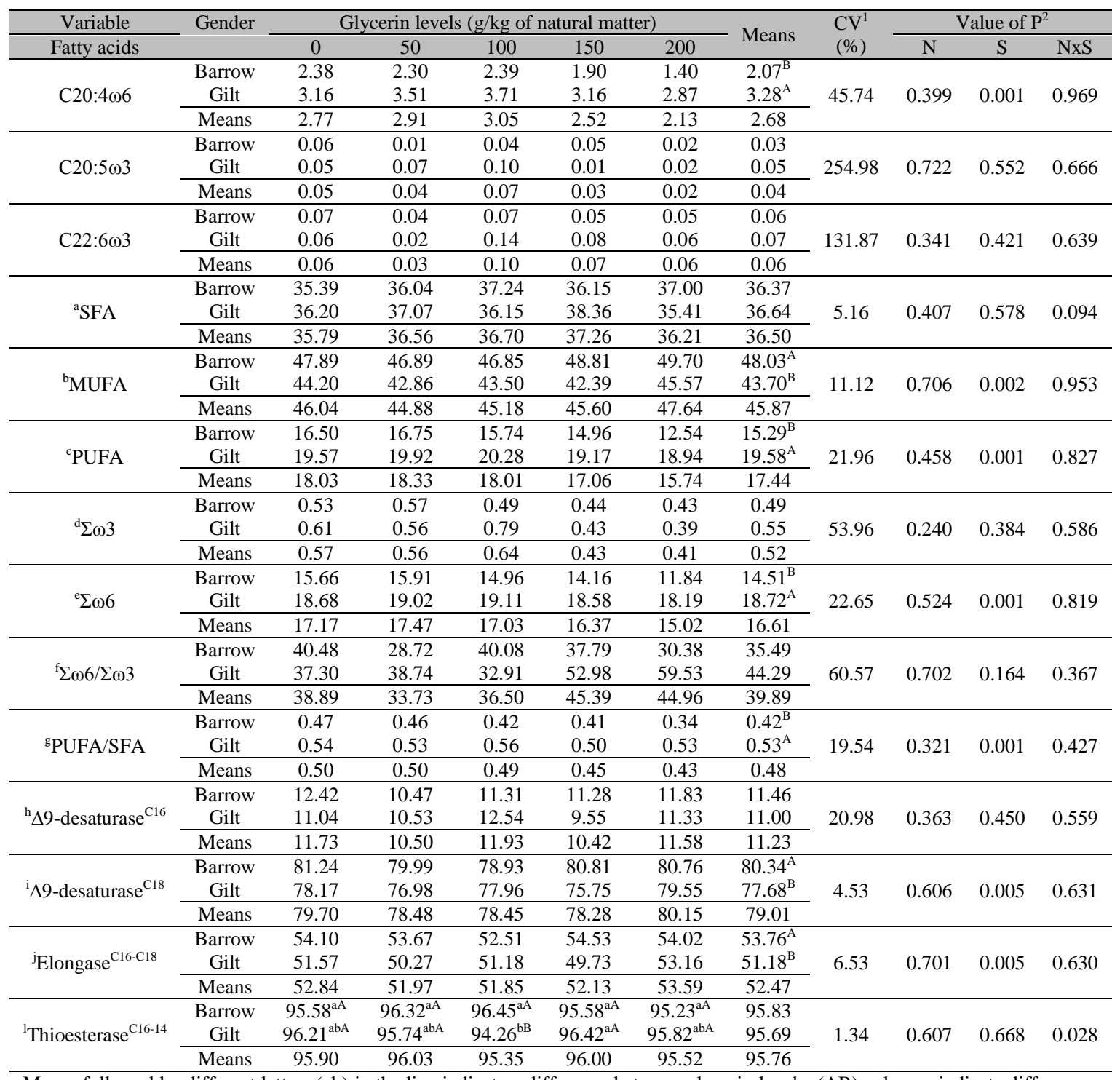

Means followed by different letters (ab) in the line indicate a difference between glycerin levels; (AB) columns indicate differences between sex by the SNK test $(\alpha=0,05)$. ${ }^{1}$ Coefficient of variation; ${ }^{2} \mathrm{~N}, \mathrm{~S}, \mathrm{~N}$ x S: effect of the supplementation with glycerin level, sex and its interaction, respectively; ${ }^{a}$ Sum of SFA (C12:0 + C14:0 + C15:0 + C16:0 + C17:0 + C18:0 + C20:0); ${ }^{b}$ Sum of MUFA (C14:1 cis-9+C16:1 cis-9+ C17:1 cis-9+C18:1 cis-9+C20:1 cis-9 + C22:1 cis-9); ${ }^{\mathrm{c}}$ Sum of PUFA $(\mathrm{C} 18: 2 \omega-6+\mathrm{C} 18: 3 \omega-6+\mathrm{C} 18: 3 \omega-3+$ $\mathrm{C} 20: 4 \omega-6+\mathrm{C} 20: 3 \omega 6+\mathrm{C} 20: 3 \omega 3+\mathrm{C} 20: 5 \omega 3+\mathrm{C} 22: 6 \omega-3) ;{ }^{\mathrm{d}}$ Sum of PUFA of the n-6 series $(\mathrm{C} 18: 2 \omega-6+\mathrm{C} 18: 3 \omega-6+\mathrm{C} 20: 4 \omega-6+$ $\mathrm{C} 20: 3 \omega 6)$; ${ }^{\mathrm{e}} \mathrm{Sum}$ of PUFA of the $\mathrm{n}-3$ series $(\mathrm{C} 18: 3 \omega-3+\mathrm{C} 20: 3 \omega 3+\mathrm{C} 20: 5 \omega 3+\mathrm{C} 22: 6 \omega-3)$; ${ }^{\mathrm{f}} \mathrm{Ratio}$ PUFA/SFA $(\mathrm{C} 18: 2 \omega-6+\mathrm{C} 18: 3 \omega-$ $6+\mathrm{C} 18: 3 \omega-3+\mathrm{C} 20: 4 \omega-6+\mathrm{C} 20: 3 \omega 6+\mathrm{C} 20: 3 \omega 3+\mathrm{C} 20: 5 \omega 3+\mathrm{C} 22: 6 \omega-3) /(\mathrm{C} 12: 0+\mathrm{C} 14: 0+\mathrm{C} 15: 0+\mathrm{C} 16: 0+\mathrm{C} 17: 0+\mathrm{C} 18: 0+$ C20:0); ${ }^{\mathrm{g}}$ Ratio $\omega-6 / \omega-3$ ( $\left.\Sigma \omega-6 / \Sigma \omega-3\right)$; ${ }^{\mathrm{h}}$ Index of C16 desaturase activity=100 [(C16:1 cis-9)/(C16:1 cis-9+C16:0)]; ${ }^{\mathrm{i}}$ Index of C18 desaturase activity $=100\left[\left(\mathrm{C} 18: 1\right.\right.$ cis-9)/(C18:1 cis-9+C18:0)]; ${ }^{j}$ Index of $\mathrm{C} 16$ to $\mathrm{C} 18$ elongase activity $=100[(\mathrm{C} 18: 0+\mathrm{C} 18: 1$ cis9)/(C16:0+C16:1 cis-9+C18:0+C18:1 cis-9)]; Index of C16 to C14 thioesterase activity=100 [(C16:0)/(C16:0+C14:0)].

In the metabolism of polyunsaturated fatty acids $\omega-6$ and $\omega-3$ PUFA, the desaturation and elongation reactions are mediated through enzymes desaturase and elongase $(\Delta 4, \Delta 5, \Delta 6)$, resulting in the synthesis of highly unsaturated fatty acids, which afterwards are esterified into phospholipids and will go to constitute the cell membranes, contributing to its fluidity, in addition to being precursors of prostaglandins, thromboxanes and leukotrienes (Nakamura and Nara, 2004). As the affinity of enzyme $\Delta 6$ desaturase is greater for fatty acids $\omega-3$, it will need smaller amounts of these in relation to $\omega-6$ for the production of the same amount of the product (Palmquist, 2009). Thus, in this work, in both cuts of swine gilts' meat, we found a greater 
amount of the fatty acids linoleic (C18:2 $\omega 6 \mathrm{c})$

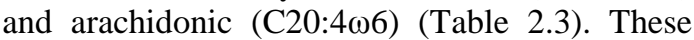
results suggest that in the gilts there is possibly a poorer activity of $\Delta 6$ desaturase and consequent greater activity of $\Delta 5$ desaturase, where as in the Barrows that behavior would be inverse, since smaller amounts of linoleic acid and greater of 11,14,17-Eicosatrienóico (C20:3 103 ) were found in these animals.

The sows' meat presented higher proportions of polyunsaturated fatty acids in relation to the saturated ones (PUFA/SFA) for both the cuts (Table 2.3) according to the glycerin level of $150 \mathrm{~g} / \mathrm{kg}$ in the diets in the loin for the total of polyunsaturated fatty acids, the series $\omega 6$, arachidonic acid with an average superior proportion of 1.79 as high as this component in relation to the amount found in the barrows. This behavior can be related to increased activity of the enzymes desaturase $(\Delta 6)$ and elongase in gilts, since the increase of the glycerol levels would promote greater synthesis of triglycerides, these being utilized for the production of polyunsaturated fatty acids in this category, while for the barrows there would be greater formation of SFA (Nuernberg et al. (2005).

No effect of the use of crude glycerin and sexual category upon the values of cholesterol in the loin of $87.25 \mathrm{mg} / 100 \mathrm{~g}$ was found (Table 4), while for the ham, there was interaction between these two factors, presenting an average value of $84.75 \mathrm{mg} / 100 \mathrm{~g}$. Those results are superior to the ones reported for pork in both the cuts (42mg/100g for loin and 49mg/100g for the ham) by Bragagnolo and Rodrigues-Amaya (2002).

Table 4. Mean of the index and cholesterol according to the level of glycerin and gender in the muscle Longissimus dorsi (loin) and Semimembranosus (ham)

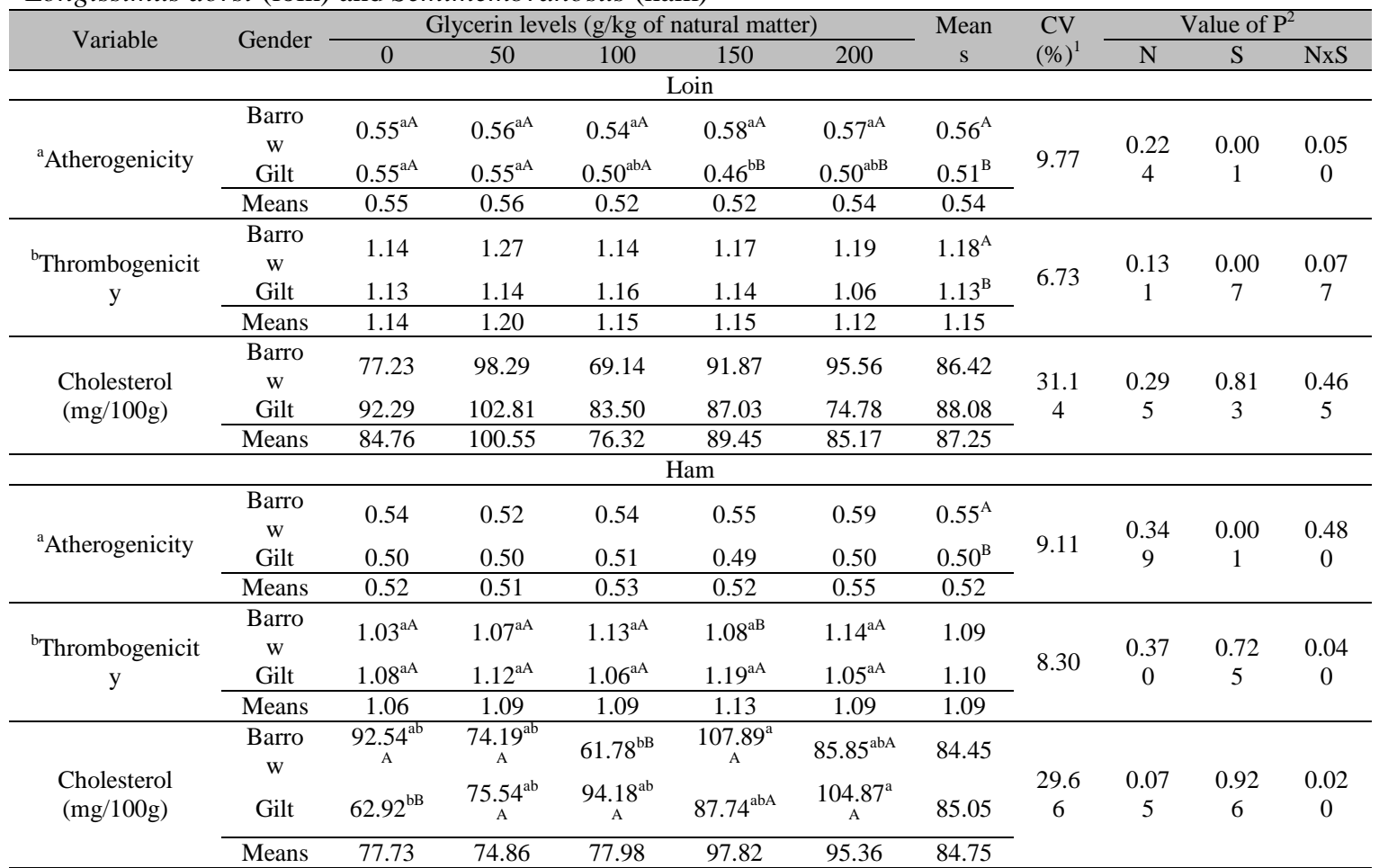

Means followed by different letters (ab) in the line indicate a difference between glycerin level; (AB) columns indicate differences between sex by SNK test $(\alpha=0,05)$. ${ }^{1}$ Coefficient of variation; ${ }^{2} \mathrm{~N}, \mathrm{~S}, \mathrm{~N}$ x S: effect of the supplementation with glycerin level, sex and its interaction, respectively. ${ }^{\mathrm{a}}$ Index of atherogenicity $=[4(\mathrm{C} 14: 0)+\mathrm{C} 16: 0] /($ Sum SFA + Sum PUFA $)$, ${ }^{\mathrm{b}}$ Index of thrombogenicity $=(\mathrm{C} 14: 0+\mathrm{C} 16: 0+\mathrm{C} 18: 0) /[(0.5 \mathrm{x} \Sigma \mathrm{MUFA})+(0.5 \mathrm{x} \Sigma \omega 6)+(3 \mathrm{x} \Sigma \omega-3)+(\Sigma \omega-3 / \omega-6)]$.

In the ham there was an interaction between the levels of glycerin and gender for the amount of cholesterol in the meat (Table 4). For the gilts, there was an effect and the amount of cholesterol increased according to the level of glycerin in the diet, while in the barrows high means were found in the $150 \mathrm{~g} / \mathrm{kg}$. 
This increase in the amount of cholesterol in the meat of the gilts according to the dietary glycerin level may be related to the increased need of synthesis of progesterone and/or estradiol, since from cholesterol sex hormones are synthesized. The process of biosynthesis of cholesterol and triacylglycerols is similar and depends on a source of glicerol-3-phosphate (glicerol-3-P), which is obtained through the action of the enzyme glycerol kinase upon glycerol, with further production of pyruvate, where this is utilized to produce acetyl-coA, which is the precursor for the cholesterol synthesis (Boyle, 2005). As in the barrows, there is no production of steroid hormones, possibly the different amounts of glycerol fed in the diet determine that range since acetyl-coA can be utilized for synthesis of other compounds as lipids, ketone bodies and energy production via the Krebs cycle.

Considering the nutrient allowances of the World Health Organization (World Health Organization, 2003) stating that the PUFA/SFA ratio should be higher than 0.4 ; it is found in this work that in both the cuts, the gilts presented better results (Table 4) and that only in the loin of barrows no values above that index were found. For human diets, a consumption proportion of $4: 1$ in relation to the fatty acids $\omega 6 / \omega 3$ is desirable. Nevertheless, in the meat of the animals in this study the results showed average values of $\omega 6 / \omega 3$ ratio of 34.69 in the loin and of 39.89 in the ham, which stands for 9 to 10 times the recommended, which constitutes a risk factor for the development of certain types of cancer and heart diseases if considering only its consumption (World Health Organization, 2003).

According to Wood et al. (2003), this is one of the undesirable aspects of pork, brought about by the high amount of linoleic acid present in the ingredients of the feeds which are given in the raising system, which has led many workers to seek alternatives such as the supplementation in swine feeding with soil sources rich in w3 (Nuernberg et al., 2005; Tikk et al., 2007), conjugated with linoleic acid (Martin et al., 2008) and monounsaturated fatty acids (Mas et al., 2010, Realini et al., 2010) .

The determination of the indices of atherogenicity and thrombogenicity in the loin showed the poorest indices for the meat of barrows; while in the ham there was a difference for the index of atherogenicity with best results for the gilts (Table 4). These indices are related to the amounts of saturated, polyunsaturated fatty acids and those of the series $\omega 6$, being a health indicator associated with the risk of cardiovascular disease according to the lipid composition of the food (Turan et al., 2007). In that way, the lower the indices of atherogenicity and thrombogenicity of a given products are, the better its consumption will be for one's health.

The indices of atherogenicity and thrombogenicity found in this work are similar to the results reported by Tonial et al. (2010) for salmon (0.56 and 0.23) and lower than the ones cited by Arruda et al. (2012) for lambs (0.64 and 1.37), demonstrating in that way characteristics intermediary to the meat of the two species.

In general, regardless of the gender and cut, the meat of the pigs fed crude glycerin offered characteristics favorable to its consumption, since gilts presented higher values of polyunsatured fatty acids and barrows presented higher values of monounsaturated fatty acids, mainly oleic acid which aids in the reduction of serum cholesterol, possesses anti-thrombogenic effect and inhibits the platelet aggregation.

\section{CONCLUSION}

The use of glycerin in swine feeding promoted modification in relation to the lipid profile, promoting modifications in the deposition of fatty acids, with higher amounts of glycerin in swine feeding promoting modifications regarding the lipid profile, promoting modifications in the fatty acid deposition with greater amounts of saturated and monounsaturated acids in the barrows meat and polyunsaturated acids and cholesterol in the sows.

\section{ACKNOWLEDGMENTS}

This work was funded by the Brazilian institutions: Fundação de Amparo à Pesquisa do Estado de Minas Gerais (FAPEMIG) pelo auxílio financeiro para execução deste estudo, Conselho Nacional de Desenvolvimento Científico e Tecnológico $(\mathrm{CNPq})$ and Universidade Federal de Lavras (UFLA). 


\section{REFERENCES}

ALONSO, V.; MAR CAMPO, M.; ESPAÑOL, $\mathrm{S}$. et al. Effect of crossbreeding and gender on meat quality and fatty acid composition in pork. Meat Sci., v.81, p.209-217, 2009.

ARRUDA, P.C.L.; PEREIRA, E.S.; PIMENTEL, P.G. et al. Perfil de ácidos graxos no Longissimus dorsi de cordeiros Santa Inês alimentados com diferentes níveis energéticos. Semina ciênc. agrar., v.33, p.1229-1240, 2012.

BOHAC, C.E.; RHEE, K.S.; CROSS, H.R. et al. Assessment of methodologies for colorimetric cholesterol assay of meats. J. Food Sci., v.53, p.1642-1645, 1988.

BOYLE, J. Lehninger principles of biochemistry. 4. ed. NELSON, D.; COX, M.; Biochemistry and Molecular Biology Education, v.33, 2005. $1119 \mathrm{p}$.

BRAGAGNOLO, N.; RODRIGUEZ-AMAYA, D.B. Determinação de colesterol em carne: comparação de um método colorimétrico e um método por cromatografia líquida de alta eficiência. Rev. Inst. Adolfo Lutz, v.22, p.1-13, 2002.

CERRATE, S.; YAN, F.; WANG, Z. et al. Evaluation of glycerine from biodiesel production as a feed ingredient for broilers. Int. J. Poult. Sci., v.5, p.1001-1007, 2006.

CLAPPER, J.A.; CLARK, T.M.; REMPEL, L.A. Serum concentrations of IGF-I, estradiol-17b, testosterone, and relative amounts of IGF binding proteins (IGFBP) in growing boars, barrows, and gilts. J. Anim. Sci., v.78, p.25812588, 2000 .

FOLCH, J.; LEES, M.; STANLEY, S.A. A simple method for isolation and purification of total lipids from animal tissues. J. Biol. Chem., v.226, p.479-503, 1957.

HARTMAN, L.; LAGO, R.C.A. Rapid preparation to fatty acids methyl esters. Lab. Practice, v.22, p.475-476, 1973.

HAYASHI, A.; MEDEIROS, S.R.; CARVALHO, M.H. et al. Conjugated linoleic acid (CLA) effects on pups growth, milk composition and lipogenic enzymes in lactating rats. J. Dairy Sci., v.74, p.160-166, 2007.
KAZALA, E.C.; LOZEMAN, F.J.; MIR, P.S. et al. Relationship of fatty acid composition to intramuscular fat content in beef from crossbred wagyu cattle. J. Anim. Sci., v.77, p.1717-1725, 1999.

MALAU-ADULI, A.E.O.; SIEBERT, B.D.; BOTTEMA, C.D.K. et al. A comparison of the fatty acid composition of triacylglycerols in adipose tissue from Limousin and Jersey cattle. Aust. J. Agric. Res., v.48, p.715-722, 1997.

MARTIN, D.; ANTEQUERA, T.; MURIEL, E. et al. Effect of dietary conjugated linoleic acid in combination with monounsaturated fatty acids on the meat composition and quality traits of drycured loin. Meat Sci., v.80, p.1309-1319, 2008.

MAS, G.; LLAVALL, M.; COLL, D. et al. Carcass and meat quality characteristics and fatty acid composition of tissues from Pietrain-crossed barrows and gilts fed an elevated monounsaturated fat diet. Meat Sci., v.85, p.707714, 2010.

METZ, P.A.M.; MENEZES, L.F.G.; SANTOS, A.P. et al. Perfil de ácidos graxos na carne de novilhos de diferentes idades e grupos genéticos terminados em confinamento. Rev. Bras. Zoot., v.38, p.523-531, 2009.

MITCHAOTHAI, J.; YUANGKLANG， C.; WITTAYAKUN, S. et al. Effect of dietary fat type on meat quality and fatty acid composition of various tissues in growing- finishing swine. Meat Sci., v.76, p.95-101, 2007.

NAKAMURA, M.T.; NARA, T.Y. Structure, function, and dietary regulation of delta 6 , delta 5, and delta 9 desaturases. Annu. Rev. Nutr., v.24, p.345-376, 2004.

NUERNBERG, K.; FISCHER, K.; NUERNBERG, G. et al. Effects of dietary olive and linseed oil on lipid composition, meat quality, sensory characteristics and muscle structure in pigs. Meat Sci., v.70, p.63-74, 2005.

PALMQUIST, D.L. Omega-3, fatty acids in metabolism, health, and nutrition and for modified animal product foods. Prof. Anim. Scient., v.25, p.207-249, 2009.

PERINI, J.A.L.; STEVANATO, F.B.; SARGI, S.C. et al. Ácidos graxos poli-insaturados n-3 e n-6: metabolismo em mamíferos e resposta imune. Rev. Nutr., v.23, p.1075-1086, 2010. 
REALINI, C.E.; DURAN-MONTGÉ, P.; LIZARDO, R. et al. Effect of source of dietary fat on pig performance, carcass characteristics and carcass fat content, distribution and fatty acid composition. Meat Sci., v.85, p.606-612, 2010.

TEYE, G.A.; SHEARD, P.R.; WHITTINGTON, F.M. et al. Influence of dietary oils and protein level on pork quality. 1. Effects on muscle fatty acid composition, carcass, meat and eating quality. Meat Sci., v.73, p.157-165, 2006.

TIKK, K.; TIKK, M.; AASLYNG, M.D. et al. Significance of fat supplemented diets on pork quality -Connections between specific fatty acids and sensory attributes of pork. Meat Sci., v.77, p.276-286, 2007.

TONIAL， I.B.; OLIVEIRA， D.F.; BRAVO, C.E.C. et al. Caracterização físico-quimica e perfil lipídico do salmão (Salmo Salar L.). Alim. e Nutr., v.21, p.93-98, 2010.
TURAN, H.; SÖNMEZ, G.; KAYA, Y. Fatty acid profile and proximate composition of the thornback ray (Raja clavata, L. 1758) from the Sinop coast in the Black Sea. J. Fish Sci., v.1, p.97-103, 2007.

ULBRICHT, T.L.V.; SOUTHGATE, D.A.T. Coronary heart disease:seven dietary factors. Lancet, v.338, p.985-992, 1991.

WOOD, J.D.; RICHARDSON, R.I.; NUTE, G.R. Effects of fatty acids on meat quality: A review. Meat Sci., v.66, p.21-32, 2003.

WORLD HEALTH ORGANIZATION. Diet, nutrition and the prevention of chronic diseases WHO Technical Report Series, Geneva, n. 916, 2003.

ZHANG, S.K.; STALDER, T.J.; GOODWIN, K.J. et al. Effects of breed, sex, and halothane genotype on fatty acid composition of pork Longissimus muscle. J. Anim. Sci., v.85, p.583591, 2007. 